ISSN 0258-7122

Bangladesh J. Agril. Res. 37(1): 97-107, March 2012

\title{
GENETIC TRANSFORMATION IN WHITE JUTE THROUGH AGROBACTERIUM AND SALINITY SCREENING OF TRANSGENIC PLANT
}

\author{
M. N. AMIN ${ }^{1}$, ASMA KHATUN ${ }^{2}$, M. S. R. BHUIYAN ${ }^{3}$ \\ M. A. SAYED ${ }^{4}$ AND S. R. KHANDKER ${ }^{5}$
}

\begin{abstract}
The experiment was conducted to establish an efficient and reproducible protocol for the plant regeneration and genetic transformation in white Jute (Corchorus capsularis L.). The regeneration and transformation processes depend on optimum growth conditions, suitable explants and varieties. An attempt was made for Agrobacterium mediated genetic transformation in white jute varieties using gene construct conferring both salt and drought tolerance (CIPK and Gly-1) along with the marker genes. Interestingly the two varieties (CVL-1 and Tricap-1) showed the response of both callus induction and plant regeneration on a single formulation i.e. MS medium supplemented with 2.0 $\mathrm{mg} / \mathrm{l} \mathrm{BAP}$ and $0.5 \mathrm{mg} / \mathrm{l}$ IAA. Explants were dipped to liquid culture of bacteria for one minute and then transferred to co-cultivation media for 24 hours. Shoot regeneration from Agrobacterium infected cotyledon was found highest in variety CVL-1 (43\%) than Tri cap (38\%). After co-cultivation and selection histochemical GUS assay was performed in different varieties (vars. Tricap-1, CVE-3 \& CVL-1). In the transformed explants, GUS reporter gene was expressed showing blue colour in the explants tissues. Among the varieties CVE-3 showed the highest expression blue colour in the explants tissues. Those transgenic plants are transferred to salt medium and soil for evaluation.
\end{abstract}

Keywords: Media, Agrobacterium tumefaciens, Corchorus olitorius, transformation.

Abbreviations: GUS-ß-glucuronidase; LB-Luria-Bertani; NPT-neomycine phosphotransferase; Ti-tumor inducing; YMB- yeast extract mannitol broth,

\section{Introduction}

Agrobacterium tumefaciens-mediated transformation is generally used for genetic transformation of higher plants. Genetic transformation of crop plants has been evolved, which offers the ability to introduce single new character into a plant cultivar without altering of its existing traits (Gardner, 1993). Agrobacterium-mediated transformation has many advantages, such as

${ }^{1}$ Scientific Officer, Plant Breeding Division, Bangladesh Agricultural Research Institute (BARI), Gazipur-1701, ${ }^{2}$ Chief Scientific Officer, Genetic Resources and Seed Division, Bangladesh Jute Research Institute (BJRI), Manik Miah Avenue, Dhaka, ${ }^{3}$ Professor, Department of Genetics and Plant Breeding, Sher-e-Bangla Agricultural University (SAU), Sher-e-Bangla Nagar, Dhaka-1207, ${ }^{4}$ Scientific Officer, Plant Breeding Division, Bangladesh Rice Research Institute (BRRI), Gazipur-1701, ${ }^{5}$ MS Student, Department of Genetics and Plant Breeding, SAU, Sher-e-Bangla Nagar, Dhaka-1207, Bangladesh. 
low copy number of transgene, and stable inheritance of transgenes in a Mendelian fasion (Gelvin, 2003). Most Agrobacterium-mediated transformations are carried out using in vitro tissue culture. A. tumefaciens has the exceptional ability to transfer a particular DNA segment (T-DNA) of the tumor-induction ( $\mathrm{Ti}$ ) plasmid into the nucleus of infected cells where it is then stably integrated into the host genome and transcribed, causing crown gall. Thus transformation efficiency highly depends on the regeneration abilities of genotypes and explants. Transformation efficiency can be increased by the manipulation of either the plant or bacteria for enhancing competency of plant tissue and vir gene expression, respectively (Mondal et al., 2001; Chakrabarty et al., 2002). It is now possible to transform a wide range of plants, including agronomically and horticulturally important crops, flowers and trees have been genetically modified using this method (Ko and Korban, 2004; Lopez et al., 2004).

The worldwide awareness on environment and health is likely to provide new opportunities on jute due to its environment-friendly characteristics is biodegradable and its products can be easily disposed without causing environmental hazards. Considering the importance of jute in Bangladesh and limitation in improving its yield and quality, it is necessary to incorporate genes of desired traits in to the local varieties. However, there have been limited responses of different varieties towards shoot regeneration. In vitro plant regeneration and genetic transformation systems in white jute via Agrobacterium tumefaciences which would further be used for the introduction of important genes such as salt, drought tolerence gene for improvement of jute plant quality.

\section{Materials and Method}

\section{Germination of seeds on culture media}

Seeds of white Jute (vars. Tri cap, CVL-1, CVE-3) were surface sterilized by immersion in $0.1 \%(\mathrm{w} / \mathrm{v})$ Mercuric chloride for $20 \mathrm{~min}$, followed by $4-5$ washes with deionized water. All seeds were placed on the surface of the $50 \mathrm{ml}$ aliquots of hormone free agar solidified $(0.8 \%$, w/v) MS basal medium (Murashige and skoog, 1962) in $100 \mathrm{ml}$ conical flasks. In another set of experiment, surgical cotton (1 gm approx. in each flask) was used instead of agar in association with MS basal liquid medium to obtained optimum seedling production. Each flask contained $20 \mathrm{ml}$ of hormone free MS liquid medium. Cultures were placed in a growth room with $20^{\circ} \mathrm{C}$ under $1.0 \mathrm{Wm}^{2}$ of daylight fluorescent tubes with $12 \mathrm{~h}$ photoperiod. Seed germination percent and number of healthy seedling was recorded. 


\section{Callus induction, shoot and root regeneration}

Cotyledons (with attached petiole) of varieties of $C$. capsularis were cultured on MS medium supplemented with $2 \mathrm{mg} / \mathrm{l} \mathrm{BAP}$ and $0.5 \mathrm{mg} / \mathrm{l}$ IAA. The ultimate goal of in vitro technique was to production of free-living plantlets via shoot and root formation from the explants. The responses of different varieties towards shoot regeneration were found varied. When the shoot was $2-3 \mathrm{~cm}$ length, they were rescued aseptically from the cultured flasks and was separated from each other and again cultured individually on $250 \mathrm{ml}$ conical flask with freshly prepared MSO (hormone free MS medium) medium for root production. Conical flask containing plantlets was incubated at $28^{\circ} \mathrm{C}$ under a $1 \mathrm{Wm}^{2}$ of daylight florescent tube with a $12 \mathrm{~h}$ photoperiod.

\section{Agrobacterium tumefaciens strain and binary vector}

Agrobactarium tumefaciens LBA4404 harbouring the binary vector pBI121 containing selectable marker CIPK gene and screenable marker GUS gene were grown on YMB (Yeast Mannitol Broth) medium (1.0\% Mannitol, 0.04\% Yeast extract, $0.01 \% \mathrm{NaCl}, 0.02 \% \mathrm{MgSO}_{4} .7 \mathrm{H}_{2} \mathrm{O}, 0.05 \% \mathrm{~K}_{2} \mathrm{HPO}_{4}$ ) containing Kanamycin as the selective agent at $200 \mathrm{rpm}$ in a shaker at $28^{\circ} \mathrm{C}$ for overnight. Bacterial concentration was determined by visual observation. Agrobacterium from these cultures were used for infection of cotyledonary petioles of young jute plants.

\section{Explants preparation}

Cotyledonary petioles from germinated seedlings were used as explants. After seven days, cotyledons were excised from the seedlings. This was carried out by gently holding the hypocotyls with forceps, and cutting between the joint just below the shoot tip using sterilized surgical blades.

\section{Agrobacterium culture}

Two kinds of culture media were needed for the Agrobacterium strain. One for maintaining Agrobacterium stock and the other for the infection of explants. For maintenance, one single colony from Agrobacterium stocks was streaked into freshly prepared Petri dish containing YMB medium having Kanamycin. The Petri dish was sealed with parafilm and kept in room temperature for 48 h. For infection, Agrobacterium stock single streak was taken in an inoculation loop and was inoculated in a conical flask containing LB medium with $50 \mathrm{mg} / \mathrm{L}$ Kanamycin .The cultures were allowed to grow at $28^{\circ} \mathrm{C}$ to get optimum population of Agrobacterium for infection and co cultivation of explants. 


\section{Infection and incubation}

The Agrobacterium grown in liquid LB media was used for infection and incubation. To get suitable and sufficient infection of the explants, freshly excised explants were dipped into bacterial suspension for $1 \mathrm{~min}$ before transferring them to co-cultivation medium.

\section{Co-cultivation}

Following infection and incubation, the explants were co-cultured on plant regeneration medium in Petri dishes containing $2 \mathrm{mg}$ BAP and 0.5mg IAA. Prior to transfer of all explants to regeneration medium, they were blotted dry with sterile filter papers for a short period to remove excess bacterial suspension. All the explants were maintained in co-cultivation medium for 24 hours. Petri dishes containing explants were placed under fluorescent illumination with 12 hours dark cycle at $28^{\circ} \mathrm{C}$. The intensity of light was maintained at 1000 lux.

\section{Transfer to the nutrient medium and sub culturing}

Following 24 hours co-cultivation, the explants were transferred to regeneration medium consisting of MS medium supplemented with $2.0 \mathrm{mg} / 1 \mathrm{BAP}, 0.5 \mathrm{mg} / 1$ IAA and $500 \mu \mathrm{g} / \mathrm{ml}$ Cefotaxime. After 6-7 weeks, the regenerated shoots were transferred to hormone free MS medium with $250 \mu \mathrm{g} / \mathrm{ml}$ Cefotaxime. Amount of Cefotaxime was gradually reduce in every sub culturing.

\section{Transfer to salt media}

Putatively transformed shoots were transferred to $25 \mathrm{mM} / \mathrm{L}, 50 \mathrm{mM} / \mathrm{L}, 75 \mathrm{mM} / \mathrm{L}$, $100 \mathrm{mM} / \mathrm{L} ; 125 \mathrm{mM} / \mathrm{L}$ salt containing MS media.

\section{Transfer to soil}

Plantlet was rescued aseptically from the cultured flask and washed to remove the chemical associated with it and placed normal environment for hardening. Seedlings were transferred to plastic pots containing autoclaved sterilized soil mix (peat moss, perlite, and vermiculite, 5:3:2, v/v/v. Young, pampered seedlings that were grown either indoors or in a greenhouse need a period to adjust and acclimate to outdoor conditions, prior to planting in the garden. After hardening, regenerated shoots were transferred to normal soil.

\section{GUS Histochemical assay}

GUS activity was detected as described (Jefferson et al., 1998). Randomly selected co-cultivated cotyledons cultured on selective medium were used for GUS assays. Immediately after inoculation on selection medium, cotyledons were incubated in GUS staining solution at $37 \mathrm{oC}$ for $24 \mathrm{~h}$ in dark. The X-glu 
was broken down by the activity of GUS gene, which was transferred with TDNA in the cotyledonary tissue and produced a characteristic blue colour.

\section{Statistical Analysis}

The data for the characters under present study were statistically analyzed wherever applicable. The experiments were conducted in growth room and arranged in Completely Randomized Design (CRD) with five replications. The analysis of variance for different characters was performed and means were compared by Duncan's Multiple Test (DMRT).

Table 1. Varietal performance on seed germination.

\begin{tabular}{lll}
\hline Variety & No. of seeds germinated & Percent seed germination \\
\hline CVE -3 & 9.33 & 93.3 \\
CVL-1 & 9.13 & 91.3 \\
Tricap-1 & 7.99 & 79.9 \\
\hline CV (\%) & 3.93 & - \\
LSD & 0.78 & 7.86 \\
\hline
\end{tabular}

Figures followed by same letter in a column do not differ significantly at $5 \%$ level of probability by DMRT.

\section{Results and Discussion}

\section{Effect of media on seed germination}

Healthy seedling production was one of the major criteria for plant regeneration from jute explants. Seeds of C. capsularis varieties (CVE-3, CVL-1, and Tricap-1) were germinated on both agar solidified medium and surgical cotton supported liquid medium. The highest percentage of seed germination was found in variety CVE-3 (93.30\%) and the lowest was found in Tricap-1 (79.97\%) (Table.1). Percent seed germination was found to be higher on cotton supported liquid MS medium (85\%) than agar solidified MS medium (62\%) ( Table 2). This finding is supported by the findings of Naher et al. (2003) who also found the highest seed germination in the variety CVE-3 (97.33\%) in cotton supported medium. Germination of jute seed and seedling growth in cotton supported liquid medium were higher and healthier than the agar solidified medium .

Table 2. Effect of media on seed germination.

\begin{tabular}{lll}
\hline Media Support & No. of seeds germinated & Percent seed germination \\
\hline Agar & 12.0 & 62.0 \\
Cotton & 17.0 & 85.0 \\
\hline
\end{tabular}

Figures followed by same letter in a column do not differ significantly at $5 \%$ level of probability by DMRT. 
Table 3. Performance of varieties of $C$. capsularis on shoot regeneration.

\begin{tabular}{l|c|c}
\hline Varieties & \multicolumn{1}{|c|}{$\begin{array}{c}\text { No. of explants showing shoot } \\
\text { regeneration }\end{array}$} & Percent shoot regeneration \\
\hline CVE 3 & $5.80 \mathrm{a}$ & $64.2 \mathrm{a}$ \\
CVL-1 & $4.80 \mathrm{~b}$ & $53.3 \mathrm{~b}$ \\
Tricap 1 & $3.80 \mathrm{c}$ & $50.3 \mathrm{~b}$ \\
\hline
\end{tabular}

Figures followed by same letter in a column do not differ significantly at 5\% level of probability by DMRT

\section{Shoot regeneration on media}

Shoot regeneration was the highest in CVE-3 (64.27\%) followed by CVL-1 (53.30\%) and Tricap-1 (50\%) (Table 3). High responsive genotype CVE-3 for callus induction had high regeneration capacity, indicating that callus induction capacity is related to regeneration of shoot. This result is similar to the findings of Khatun (2001) (plate-1).
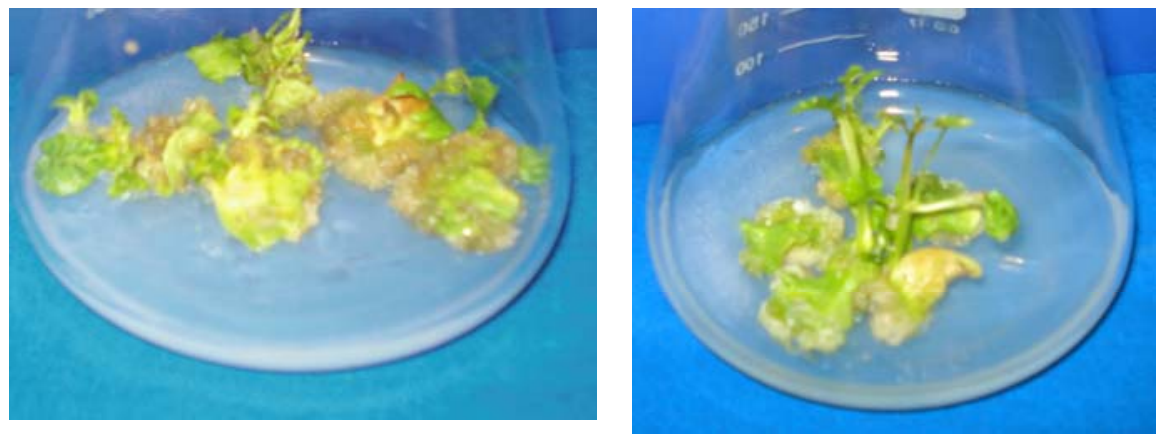

Plate 1. Shoot regeneration of CVE-3 explants on MS + $2 \mathrm{mg} / \mathrm{l} \mathrm{BAP} \mathrm{+} 0.5 \mathrm{mg} / \mathrm{l}$ IAA medium

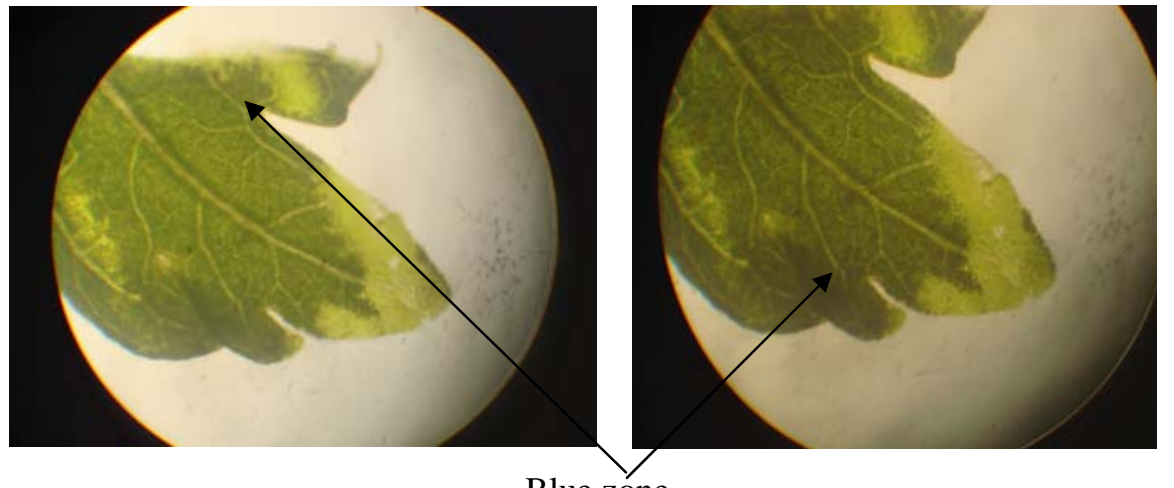

Blue zone

Plate 2. GUS positive tissues showing in leaf section of variety CVL-1-(cipk)1 


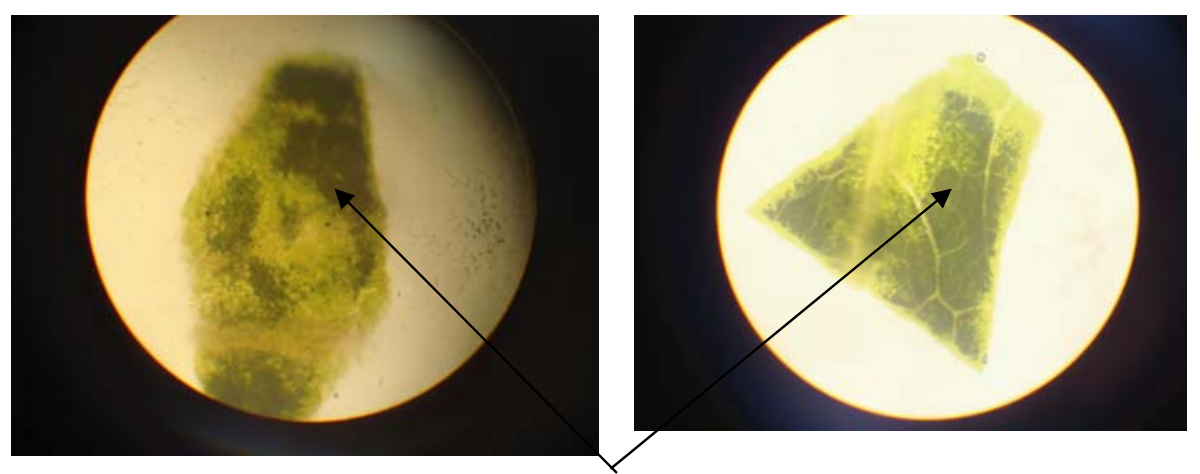

Blue zone

Plate 3. GUS positive tissues showing in leaf section of Tri cap-1.

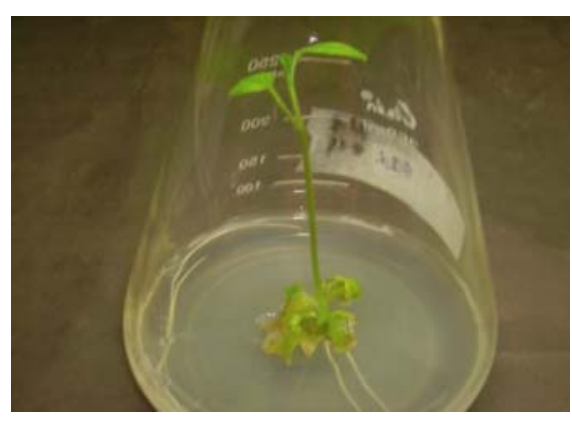

A. Plantlet regeneration in $25 \mathrm{mM} \mathrm{NaCl}$ salt concentration

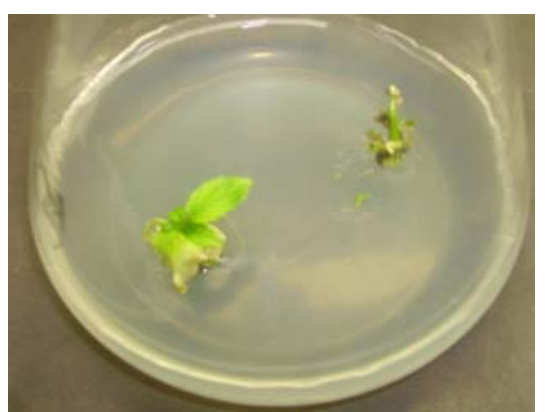

B. Plantlet regeneration in $50 \mathrm{mM} \mathrm{NaCl}$ salt concentration

Plate 4. Salt tolerance profile of Ps GLY-I gene transformed regenerating plants at different salt concentration (variety CVL-1)

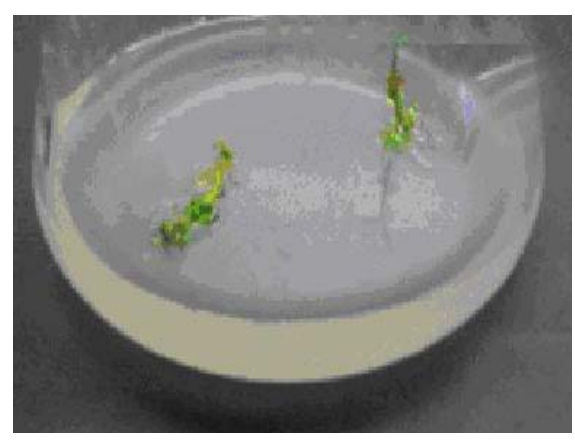

C. Plantlet regeneration in $75 \mathrm{mM} \mathrm{NaCl}$ salt concentration

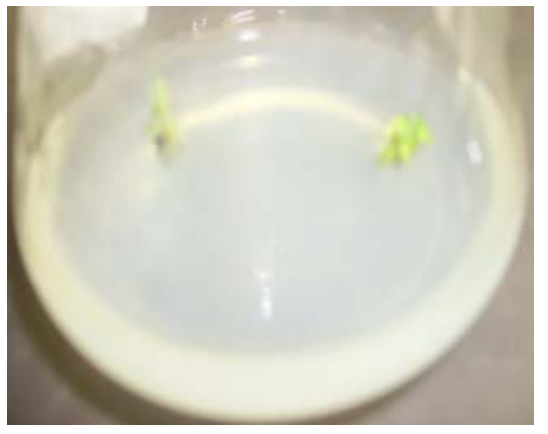

D. Plantlet regeneration in $100 \mathrm{mM} \mathrm{NaCl}$ salt concentration

Plate 4. Salt tolerance profile of Ps GLY-I gene transformed regenerating plants at different salt concentration (variety CVL-1) 


\section{Agrobacterium culture and incubation of explants}

The Agrobacterium strain grown in liquid YMB medium was used for infection and incubation. Shoot regeneration from Agrobacterium-infected cotyledons was found to be the highest in CVL-1 (43.00 \%) followed by CVE-3 (38.67\%). Shoot regeneration from Agrobacterium-infected cotyledons was found to be the lowest in Tricap-1(33\%) (Table 4).

Table 4. Performance of varieties of $C$. capsularis on percent shoot regeneration and average number of shoots from Agrobacterium infected cotyledon.

\begin{tabular}{l|l|l|l}
\hline \multicolumn{1}{c|}{ Variety } & $\begin{array}{c}\text { No. of cotyledons } \\
\text { infected }\end{array}$ & $\begin{array}{c}\text { Percent shoot } \\
\text { regeneration }\end{array}$ & $\begin{array}{c}\text { Average number of shoots } \\
\text { produced by each } \\
\text { cotyledon }\end{array}$ \\
\hline CVE-3 & 60 & $38.6 \mathrm{ab}$ & $11.3 \mathrm{~b}$ \\
CVL-1 & 60 & $43.0 \mathrm{a}$ & $14.3 \mathrm{a}$ \\
Tri cap-1 & 60 & $33.0 \mathrm{~b}$ & $8.66 \mathrm{c}$ \\
\hline CV(\%) & 6.83 & 4.17 \\
LSD & 6.045 & 1.77 \\
\hline
\end{tabular}

Figures followed by same letter in a column do not differ significantly at $5 \%$ level of probability by DMRT

\section{Co-cultivation and histochemical GUS assay}

After infection of the explants in Agrobacterium suspension culture, the explants were transferred to co-cultivation medium. Following incubation and cocultivation with Agrobacterium, transformation ability was monitored through histochemical assay of GUS reporter gene in explants tissue. Transient GUS assay was done at the end of co-cultivation with randomly selected $20 \%$ inoculated explants tissue. In the GUS assay, conspicuous GUS positive (blue color) region were detected in the explant surface (Plate 2 and Plate 3 ).

Following GUS histochemical assay, it was found that all the three varieties showed positive responses towards transformation. Following infection and cocultivation with the strain LBA4404, the cotyledons attached with petioles were cultured on plant regeneration medium containing Cefotaxime $500 \mu \mathrm{g} / \mathrm{ml}$ for shoot development. The average number of shoots produced by each cotyledon was also the highest in CVL-1 (14.33) and the lowest in Tri cap (8.66). Control explants did not show response to the assay. For selection of transformed cells and tissues, the callus proliferating shoots were transferred to selection and regeneration media containing $50 \mathrm{mg} / \mathrm{L}$ Kanakycin and $500 \mu \mathrm{g} / \mathrm{mL}$ Cefotaxime. In presence of Kanamycin (100 mg / ) in the selection media greatly influenced 
by the emergence of transgenic shoot from the transformed callus. A few of the calli continued to grow and differentiate into shoots. Among the varieties CVE-3 shows the highest response in GUS test. Those transgenic plants are transferred to salt medium and soil for evaluation (Table 5).

Table 5. Influence of explants on transformation as assessed through GUS histochemical assay.

\begin{tabular}{l|l|l|l|l}
\hline Variety & $\begin{array}{c}\text { No. of explants } \\
\text { infected }\end{array}$ & $\begin{array}{c}\text { No. of } \\
\text { explants } \\
\text { assayed for } \\
\text { GUS }\end{array}$ & $\begin{array}{c}\text { No. of } \\
\text { explants+ve for } \\
\text { GUS }\end{array}$ & $\begin{array}{c}\text { \% of GUS +ve } \\
\text { explants }\end{array}$ \\
\hline CVE-3 & 60 & 10 & 9 & 90.00 \\
Tricap-1 & 60 & 10 & 8 & 80.00 \\
CVL1 & 60 & 10 & 8 & 80.00 \\
\hline
\end{tabular}

Figures followed by same letter in a column do not differ significantly at 5\% level of probability by DMRT.

\section{Selection of explants under various salt concentrations}

For the evaluation of salt tolerant genes transformation in the jute varieties was done using in vitro method under controlled conditions. MS media supplemented with $\mathrm{NaCl}$ salt concentrations (25, 50, 75, 100 and $125 \mathrm{mM}$ ) was used for salt tolerance testing of transformed plants. Transformed plants of the three varieties were able to survive up to $100 \mathrm{mM}$ salt concentration while the controlled plants died out at 50mM (Plate-4). All of the varieties survived at (50\%) up to $75 \mathrm{mM}$ salt concentrations. However, in case of $100 \mathrm{mM}$, the survival rate was $20 \%$ (Table 6).The explants were albino at $125 \mathrm{mM}$. The survival of transformed plants at $75 \mathrm{mM}$ indicates the transformation and expression of the genes in the varieties. The above mention research showed the possibility of the salt tolerant variety development using recombinant DNA technology.

Table 6. Selection of explants under various salt concentrations.

\begin{tabular}{l|l|l|l|l}
\hline $\begin{array}{c}\text { Treatments } \\
\text { (Salt concentration) }\end{array}$ & $\begin{array}{c}\text { No. of } \\
\text { explants } \\
\text { assayed }\end{array}$ & $\begin{array}{c}\text { No. of explants } \\
\text { survived }\end{array}$ & $\begin{array}{c}\text { Percentage of } \\
\text { survived } \\
\text { plants }\end{array}$ & $\begin{array}{c}\text { Days of } \\
\text { survival }\end{array}$ \\
\hline $25 \mathrm{mM}$ & 10 & 10 & 100 & 60 \\
$50 \mathrm{mM}$ & 10 & 9 & 90 & 30 \\
$75 \mathrm{mM}$ & 10 & 5 & 50 & 15 \\
$100 \mathrm{mM}$ & 10 & 2 & 20 & 8 \\
$125 \mathrm{mM}$ & 10 & 0 & 00 & 5 \\
\hline
\end{tabular}




\section{Regenerated plantlets transfer to soil}

After root production, transgenic plantlets were subjected to hardening (Plate 5) and then transferred to sterilize soil successfully and after shoot and root development it was transferred to normal soil. Among the transgenics only three plants survived up to maturity (Plate 6).
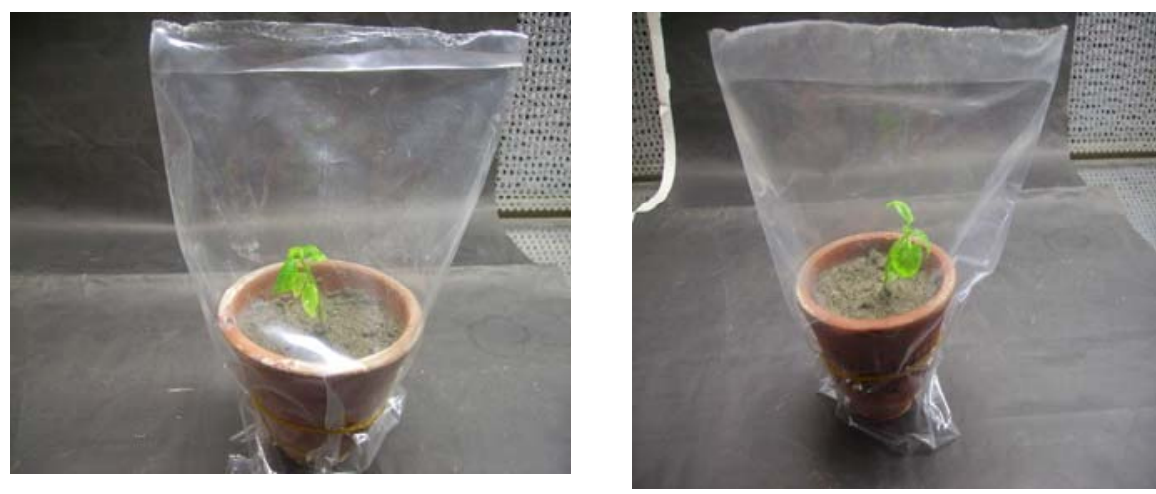

Plate 5. Hardening of regenerated plantlets (CVL-1)
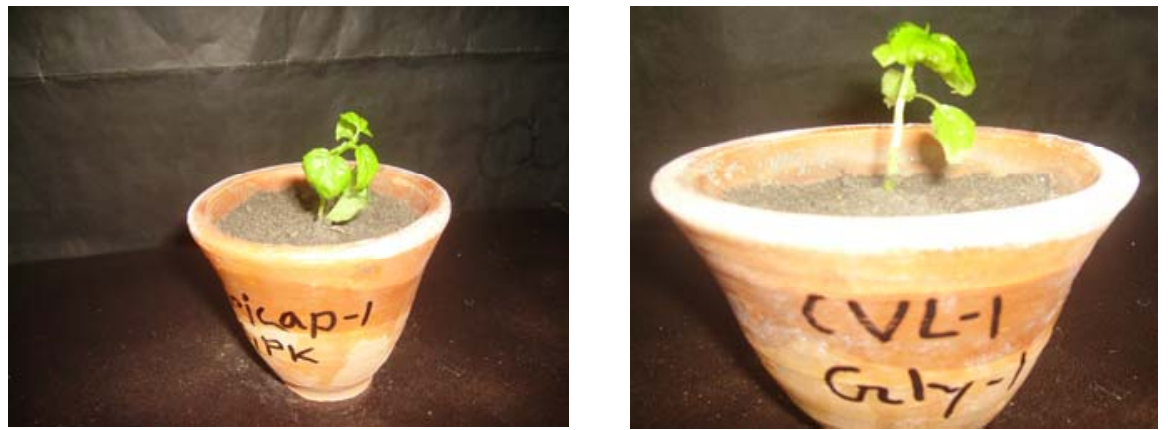

Plate 6: Transgenic seedlings transferred to sterilized soil

\section{References}

Chakrabarty R, N. Viswakarma, S. R. Bhat, P. B. Kirti, B. D. Singh and V. L. Chopra. 2002. Agrobacterium-mediated transformation of cauliflower: optimization of protocol and development of Bt-transgenic cauliflower. J Biosci. 27: 495-502

Gardner, R.C. 1993. Gene transfer into tropical and subtropical crops. Scientia Hort. 55: 65-82.

Gelvin S. B. 2003. Agrobacterium-mediated transformation the biology behind the "Gene Jocking” tool. Microbiol Mol Biol Rev. 67: 16-37.

Mondal T. K., A. Bhattacharya, P. S. Ahuja and P. K. Chand. 2001. Transgenic tea (Camellia sinensis [L.] O.Kuntze cv. Kangra Jat) plants obtained by Agrobacteriummediated transformation of somatic embryos. Plant Cell Rep. 20: 712-720 
Khatun, A. 2001. Varietal improvement of jute through Agrobacterium mediated transformation. Final Report, Contract Research Project, Bangladesh Agriculture Research Council. pp. 4-17.

Ko T and S. Korban. 2004. Enhancing the frequency of somatic embryogenesis following Agrobacterium-mediated transformation of immature cotyledons of soybean (Glycine max (L.) Merrill). In Vitro Cell Dev Bio-plant 40: 552-558

Ghosh, PK and Chatterjee (1990) Regeneration of plant from hypocotyl-derived callus tissue of Jute( Corchorus capsularis L.). Cell Chrom Res. 13: 26-29

Murashige T and Skoog F (1962) A revised medium for rapid growth and bioassays with tobacco tissue cultures. Physiol. Plant 15(3): 473-497

Naher, Z., A. Khatun, Mahbub, M. A. Alim and A. B. Siddique. 2003. Influence of genotypes on plant regeneration from cotyledons of C. capsularis L. Biotechnol. 2(1): 44-51. 